\title{
Anthós
}

\section{Privatizing the Second Gender: The Origins of Private Property and its Relation to Female Sexual Enslavement in the Capitalist Economy}

Van Thao Tran

Economics

Follow this and additional works at: https://pdxscholar.library.pdx.edu/anthos

Part of the Economics Commons, and the History Commons Let us know how access to this document benefits you.

\section{Recommended Citation}

Tran, Van Thao (2017) "Privatizing the Second Gender: The Origins of Private Property and its Relation to Female Sexual Enslavement in the Capitalist Economy," Anthós: Vol. 8: Iss. 1, Article 6.

https://doi.org/10.15760/anthos.2017.61

This open access Article is distributed under the terms of the Creative Commons Attribution-NonCommercialShareAlike 4.0 International License (CC BY-NC-SA 4.0). All documents in PDXScholar should meet accessibility standards. If we can make this document more accessible to you, contact our team. 
Privatizing the Second Gender: The Origins of Private Property and its Relation to Female Sexual Enslavement in

the Capitalist Economy

Van Thao Tran

In this inquiry I seek to establish an association between the origins and evolutionary patterns of private property and the insidious phenomenon of the female sex trafficking industry. In order to assess the transformation of private property in economic society from its earliest stages to current times, I have utilized the seminal works of Thorstein Veblen and Friedrich Engels, both of whom are historically recognized as valued critics and thinkers. Veblen, best known for his introduction of evolutionary theory to economics, assesses that private property - characterized first by the privatization of women in conquest - emerged as humanity traversed through the stages of evolutionary development as distinguished by its technological progress: primitive savagery, the era of communal tribes and huntergatherers; barbarism, the era of technological advancements towards settlement, cultured food production, and warring tribes; and civilization, the era of solidified workings of industrial production, social organization, and established States. Engels, similarly, follows an anthropological framework to theorize that the subjugation of women arises out of a deepening of productive relations in class society, and works to uphold the institution of private property in the patriarchal traditions of the family unit.

We begin with a development of private property as an evolutionary institution. Conventional ideologies of economics contend that the ownership of private property can be articulated 
simply as an appropriation of labour over goods and services resulting from the processes of production, and that the "owner" of the means of production are entitled by natural rights to the pecuniary rewards that they reap. In his article The Beginnings of Ownership (1898) as published by the American Journal of Sociology, Thorstein Veblen not only critiques this definition as being outdated and inconsistent due to the fact that the means of production in and of itself cannot belong to any single proprietor in the integrated industrial community within which we live, but also divulges its insubstantial valuation of private property as lacking evolutionary-institutional context. Veblen $(1898,352$ - 365) investigates the conception of private property not as a natural right of man, but rather through his understanding of anthropological evolution and human instincts - and through his inductions, he teaches us that the origins of private property began with the male appropriation of women as emblems of barbaric emulation.

As Veblen $(1898,355$ - 360) analyzes, the emergence of private property cannot be explained by any kind of natural entitlement over the acquisition and procurement of goods, or the habitual and extensive use of those goods. In the primitive savage stage of human evolution, a person had no concept of ownership; rather, he had a relationship with artifacts that acted as organic extensions of his character, things that made up his identity within what Veblen calls the "quasi-personal fringe". This goes beyond ownership because ownership implies impersonality: something which is owned must be acquired and thus it is a separate thing from the owner. A scent or a voice cannot be owned; it simply is, it simply 
belongs. Such was the same ideal imprinted in the savage's perception of personal belongings. Goods procured for consumption were also prohibited from being appropriated by any single person, for in the tradition of the savage communes it belonged to the common group. So, private property is not a natural right of man because early man had no natural knowledge of it; it is a habit of thought that had to be learned and habituated, evolving into an institution over time. This period of transformation took place during the transition of mankind from peaceable savages into predatory barbarians, wherein the invidious instincts for emulation took force and perpetuated predatory habits of war, prowess, and trophyism. Veblen (1898, 361 - 362) assesses that during the first stages of barbarism, overpopulation compelled men to war with other groups out of territorial hostility, which became habituated activities that promoted predatory instincts, eventually leading to the predatory habits of looting and exploiting the enemy. However, seized goods were not owned by any individual, but were rather shared amongst the group for consumption in a communistic setting akin to the ancestral primitives. At this stage, material acquisition was not for personal appropriation because group-regarding behaviors were still the most beneficial to the individual's survival despite the rise of exploitative predation and emulation, and personified objects only made up the quasi-personal fringe; private property was still an undiscovered concept. Veblen $(1898,364-365)$ then suggests that the first piece of appropriated property was not a resource, land, or good, but rather human captives - specifically women. 
According to another article titled The Barbarian Status of Women, Veblen $(1899,503$ - 514) theorizes that the institution of marriage came about as the first form of privatization and as the beginning of the patriarchy. Women's status in barbarian society had slowly deteriorated into a lowly, servile class due to a deepened male distinction between the masculine glory of war and hunting sports, and the feminine attributes that were observed as weak and ignoble. As the barbarian era became more and more industrialized - that is, more immersed in the processes of production - women's position as heads of household became more so insignificant. To the barbarian man, women held no specific utility to the group as a whole outside of menial labour and could not be used like objects of personal embellishment. They were also physically less able to avoid captivity and easier to subjugate due to their inferior status, and as such, became preferable objects of plunder. In the male-dominant barbarian society, women's utility was increasingly their function as war prize; it became customary to take the enemy's women in servant and master bondage to parade the victory of battle and satisfy the instinct of invidious emulation.

As the tradition disseminated into routine life in the form of marriage, it was sanctified as a sort of ritualistic taking of all women into the servitude of their husbands. As Veblen $(1898,364)$ summates, "this ownership-marriage seems to be the original both of private property and of the patriarchal household." Though Veblen has developed a succinct and incisive theory to explain the emergence of private property as an evolutionary institution, it remains unclear as to how a mere distinction between the two sexes created a class divide 
over the concepts of drudgery and honorable work. It can be observed that women and men in the peaceable era of savagery still had distinctive yet egalitarian positions of power - women presided over the home, and men over the hunt. Veblen's theory asserts that the emergence of private property is an institution of sexist origins, but how did the division of labour between the sexes become an institutional segregation of an exploitative upper class and a subservient lower class?

Friedrich Engels provides a speculative answer to this question in his best-renowned work: The Origin of the Family, Private Property, and the State $([1884], 1972$.$) It must be noted that this is a$ controversial piece often disputed amongst modern anthropologists. Though Engels has made some faulty assertions and shortcomings in his foresight about the true complexity of family and society, the foundational knowledge from which he built is rich, his analyses wellreasoned, his ideas revolutionary, and the overarching theoretical structure itself stands as a compelling and enduring vision that has inspired much social inflection, thus propelling the debate to greater heights. In his inquiry, Engels investigates the evolution of the classless communes into the deeply hierarchical societies utilizing data gathered from the lifelong research of pioneer anthropologist, Lewis H. Morgan. The most prominent discovery Morgan had made from his immersive exploration of tribal life is that the tenets of civilized society - namely the state, family, and private property - did not exist in prehistoric times, but were rather evolved out of the transitory period between savagery and barbarism. Engels converges this knowledge with his own understandings of political economics to 
advance a revolutionary theory: the classist division of labour, and of the sexes, was birthed in the early sedentary stages of barbarism where major technological changes gave rise to the interest of proprietorship over wealth-generating surplus; class exploitation and female oppression simultaneously emerged as institutions to uphold the system of private property, both of which perpetuate to this day.

Engels' understanding involves an extensive study of Morgan's stages of marriage: the savage's group marriage, the barbaric pairing family, and the civilized monogamous family. The stage of radical change began with the evolutionary track of the pairing family in culmination with the pastoral and agricultural revolutions. According to Engels (1972, 59 - 118), the pairing family is the final evolution of the human family unit, which came about through the natural elimination of incestuous practices found in primitive group marriages. The barbaric pairing family is a social structure that recognizes one natural mother and one natural father as paternal figures in a family unit. This familial structure developed during the late savage to very early barbarian stage; as such, the family was still communistic in their relations, wherein the common goods were shared equally amongst all members and all productive activities relied on the network of kinship. Wealth was circulated through matrilineal lines, and no legal bonds tied the mother to the father. The mother right over the familial lineage and inheritance maintained its secularity for she remained the only parent who the children could be traced back to; so, her position and productive labour over the household was still one of equal status to the father who provided from the forest and game. However, drastic economic 
and industrial changes soon altercated the pairing family structure towards patriarchal monogamy and destroyed the female prescience over the household, ending with the victorious rise of private property over communal ownership and the creation of the patriarchal presence.

As Engels (1972, 86 - 89) teaches us, the cultivation of agriculture and domestication of cattle were the social catalysts that forever transformed the communistic savage into the industrial barbarian. The appropriation of surplus garnered from these technological advancements soon proliferated and became an economic tenet in human life, ushering out the era of hunting and gathering and institutionalizing the pastoral and agricultural society. It is during this time that slavery first took form to eventually become a basis of labourous civilization, though it was at first primitive in application; this also signified the frugal beginnings of female abduction and exchange for marriage and sexual purposes. As the barbarian industrial life became more established in the economics of trade and barter, the father began to domineer proprietorship over the household. Traditionally the mother held the highest power in the household, while the father commanded the tools and procurement of food. As sedentary economics pervaded familial life, the father gained ownership over the surplus produced by the herds and fields. This increased power over food provisions and the accumulation of surplus wealth led to his gaining control over the division of the commons within the household - this represents the beginnings of gender inequality, the uneven distribution of wealth based on the division of labour, and the introduction of private property within the household. 
Finally, the usurpation of the matriarch in the household came about as the husband-father revised inheritance rules to keep his riches to his own children, overthrowing the matrilineal line and transferring the female rights and the child rights into the hands of the patriarchy. As Engels $(1972,90)$ famously declared, "the overthrow of mother right was the world-historic defeat of the female sex."

To maintain his status in the household through bloodline, marriage became a bondage institution of monogamy in which the woman could not divorce; however, the man retained his own rights to both the dissolvement of marriage and of infidelity. The prostitution of enslaved women and sometimes of enslaved children for the father of the house was no defect, but was rather a perpetuation of the monogamous institution in which the wife is reduced into the position of a domestic servant and the husband continues his authority over sexual pursuits. Woman, once the head of the household and children, became a nanny and a maid. Her administrative and reproductive labour in the household thus devolved from being a highly esteemed public service into a private servitude where she receives no recognition, her voice in familial matters is subdued, and at the same time she is sequestered from all socio-economic activities. This institution of female domination is a fundamental governance of civil society because it upholds the androcentric worldview in which men should be the premiere proprietors over household, industry, and social activities. Engels $(1972,99)$ states, "the first class antagonism which appears in history coincides with the development of the antagonism between man and 
woman in monogamous marriage, and the first class oppression with that of the female sex by the male." These institutions persist well into today's societies because they are literally built into the foundation of civilization. Though it seems less obvious presently, the domination of women by the male sex has simply taken on a more obscure omnipresence in the mechanics of industry, culture, religion, and politics.

Though Engel's theory differs from that of Veblen's in its approach - Engels as more focused on the material and external forces of social evolution and Veblen on the internal psyche of predation and emulation - the two contain many fundamental similarities, the most coherent being: 1) private property is an emergent factor of the barbaric age, 2) the institution of private property has created a downward spiral, perpetuating women's descent into the lower class, and 3) the domination of women in the household through marriage is an integral aspect in maintaining male control over proprietorship. When merged, they project a model of circular causation in which the barbaric appropriation of women as emulative wife-slaves conceptually institutionalized the notion of private property which is then adhered to non-human materials such as surplus goods; coupled with the technological and economic changes made in the sedentary revolutions and the shifting dynamics into a differentiated class society, man emerged as the dominant proprietor and eventually the overtaker of woman's seat of power in the household; the tradition spreads with the continual progression of ownership-marriage and private property in an increasingly economic and industrial world. This patriarchal institution over time has become 
embedded into the very fabric of civilization, and thus the oppression of women has permeated throughout all of written history and into the present day, manifesting within household economics and social economics. Capitalism - fathered by the same predatory masculine powers - inherently represents the masculine bias and has vital vested interests in nurturing the patriarchal regime.

I further induce that Veblen's concept of the barbarian ownership-marriage reflects the conditions of slavery as is observed in the captured woman's lack of freedom, her designated servility, and her status as property. Combined with Engel's insights on the male usurpation of female dominance in the household after the sedentary revolutions, I propose that we end up with a situation of female enslavement in the family unit - and, extending beyond the domestic boundaries over the course of time, an institutionalized social system of female oppression. The wedded female bondage entailed that whatever a woman's labour procured naturally became appropriated by her master/husband, and as such she was denied any entitlement or ownership over consumable goods and services within the household. This insight can be extended into the sexual realm, wherein the woman's body and her sexual services were also regarded as her husband's property. Because a woman's work is considered menial, servile work, it can be induced that her sexual acts were also seen as lowly, vulgar services solely to be exploited by men. The male's perception of female sexuality acquires an identity of debauchery and depravity, while his own is of superior moral value. This is the birth of female sexual encumbrance, a key factor in the persistence of female sexual abuse throughout the course of history, 
and more specifically, a justification for the enormous demand of female enslavement, exploitation, and degradation in the present-day sex trafficking industry. This institutional embeddedness, the subreption of John Locke's natural rights philosophy into the practice of an increasingly predatory commercial class, and certain historical catalysts have propelled the barbaric form of female domestic slavery into a business enterprise of sexual exploitation.

\section{Evolution of Women as Property into Sexual Slavery}

The advent of female sexual slavery can be understood in the contexts of female sexual encumbrance as an evolutionary divergence from the institution of women as property. As aforementioned, this concept maintains that women lost ownership of their sexuality to their masters/husbands through the process of female enslavement in the domestic relationship. Women's reproductive labour in the house though essential to the maintenance of daily life - procured no measurable quantity of wealth or emulation in civilized society and as such was not seen as economic activity. As "unproductive" members of the patriarchal household, the fruits of the woman's labour were thus entitled to the patriarch of the house as a kind of "rent" to ensure her continued livelihood; a part of this labour involved sexual activity. Though there was a lurking perception of the female sex as inferior that preceded her eventual turn into the domestic servant-wife, it is during the institutionalization of marriage that the sexual inequality in the division of labour was borne. The gender role of man as the provider and of woman as the dependent in a marriage relationship determined that man's work is quintessential, and that woman's work 
is insignificant save for her ability to carry children and continue the paternal lineage. A woman's sexual service was thus not an object of consent but a requirement in this ownership-marriage. Female sexual encumbrance also does significantly involve the pre-marriage perception of female activities as inferior to male activities, and of the female sex acts as dishonorable or servile and of the male's as supreme. As such, the taking of a woman's sexuality was not seen as an act against her person or private property (for she had none), but rather an assertion of authority from the "better" sex. So, the woman must comply with her husband's sexual demands and at the same time accept the indignity the act brought to her.

This abusive, bipolar psychology is pervasive throughout every level of civilization as can be openly observed in historical depictions of women, and over time has evolved into a habitualized perception of the female sexual nature as dirty or sinful; and, since the monogamous relationship only applies to the subjugation of the wife, the man is theoretically free to engage in adultery. A woman's sexual service thus became profane and condemnable for the woman but was still a highly desired commodity for the man. Women were, and still are, arbitrarily dehumanized, misogynized, fetishized, and objectified for their sexuality. I suggest that a large portion of society is ingrained with the idea that women should be subjected to abuse because of their sexuality, and that sexual abuse is above all the most powerful form of masculine supremacy. So, female sexual encumbrance explains at least in part the incessant demand for derogatory sexual exploitation of women throughout the course of history. I further extend that children's rights - especially of female children - also 
deteriorated once the patriarchal family took shape because the mother no longer had the shared protective or commanding authority over her children. Children thus came under the patriarch's full proprietorship and were exposed to similar masculine abuses and demands for sexual exploitation, and thus children too became victims of sexual abuse under male domination. However, this picture does not posit the booming business of the sex trade in today's black market economy. I propose that female sexual enslavement became a profitable frontier when the predatory businessman adopted the concept of natural rights to naturalize private property under capitalist agendas - and in extension, this naturalized the perception of women as property. Then, amid the collapsing social infrastructures of Communism intersped with rapid and expansionary globalization of capitalism, the predators dwelling within the global black market rose into prominence through the lucrative and nefarious business of sex trafficking.

\section{The Sexual Subjugation of Women and Human Trafficking in a Capitalist Context}

Though Veblen and Engels have clearly established the fact that private property does not precede civilization, and that freedom and equality is not the state into which civilization was borne, we must still examine the prevalent philosophy of John Locke's natural rights as it pertains to the inception and moral logic behind the processes of economic production and consumption. Locke's introduction of natural rights came about as a means to deny sovereignty as an absolute ordainment of God, and to provide a vision 
of the state of nature where every human being is equally and freely bestowed the natural rights to appropriate the bounties of the Earth with his labour. Natural law establishes the order in which the natural rights of humankind must be observed. According to chapter 5 in Locke's The Second Treatise of Government (1689, §25 - §51), the free person in the state of nature owns his own self, and thus he owns his labour; when he exerts his labour upon a natural resource which has no previous owner, his labour and thus his self imprints upon the resource and it becomes his private property so long as he only takes enough, leaves the resource as plentiful or better, and utilizes only the force of his own labour. This conception of the origin of private property comes from a strictly theological viewpoint where civilized man was divinely endowed proprietary rights over the Earth; it entitled humans by will of God to cultivate the planet. Locke's followers could thus deduce that in order to utilize this treasure, man must put forth effort to appropriate it and submit it to his will.

I propose that this line of thought had become dangerously attractive to the burgeoning mercantile class of the time, who reduced it from a vision of stewardship into one of predatorial promise. Though Locke meant for the ideal to help perpetuate a more egalitarian society where no person could be denied their natural rights to life, liberty, and property, he had unintentionally justified the predatory mindset of ordained human domination over the world and the naturalization of private property as an unquestionable right despite its obstruction of life, liberty, and property of those who are systematically denied proprietorship. The natural rights philosophy has not only become a tenet of political ethics, but also of capitalist 
ethics. Through the processes of subreption, or the corruption of societal values with the values for pecuniary predation, the commercial interpretation of natural rights in which the capitalist serves as the primary proprietor of production (and as such its pecuniary rewards) incentivizes societal ideals of acquiring capitalistic ownership for pecuniary gain. It is possible to see here that the role of woman as property makes her useful to the capitalist agenda, especially if her function for pecuniary purposes could be utilized outside of the home where her productive work is limited and insignificant. Woman's role as "human capital" is then coupled with the culture of female sexual encumbrance, which provides an ample demand for cumbersome and derogatory sex. So, even though the female slave trade and prostitution had been going on since era of barbarism, it became clear to the capitalist that the particular profit venture of sex trafficking is completely aligned with capitalist natural rights ideology. Though the blatant abuse of women and children is no longer openly accepted in our part of society due to activism and counter movements incited by the ideal that civil rights belong to all human beings, it nonetheless permeates and contaminates our democracy, virtues, and everything we hold venerable. It happens right here on our doorstep. Thus emerged the clandestine, capitalist form of female enslavement for the purposes of sexual exploitation.

The proliferation of the human trafficking industry is a recent phenomenon, not because female sexual enslavement is new or newly re-established, but because there was never enough technological and social mobility for it to be a feasible transnational crime. I refer to the dedicated research of Prof. Louise Shelley, an authoritative scholar in 
the fields of public policy and transnational crime at George Mason University, to assess the emergence and prolific growth of human sex trafficking in the recent decades. According to her accomplished work, Human Trafficking: A Global Perspective, Shelley (2010, 37 38) identifies the sudden widespread activity of human trafficking as being indebted to the decline of Communism after the Cold War, the subsequent rise of illicit activity in the global economy coupled with outbreaks of regional conflicts, and the acceleration of globalization under capitalism.

When the Soviet Union and affiliated Communist regimes dissolved, they left behind a mass of displaced peoples, many of whom were women and children. The end of the Cold War brought about the end of polarized power and its tension of world order, and thus ensued a slew of international and regional conflicts. As Shelley (2010, 37) notes, the post-Soviet era's political and social turmoil were diagnostic of the unemployment and impoverishment of women in the regions extending from the Balkans to South East Asia, many of whom already suffered from lack of economic disposition and of deprivation as females in the household. The collapse of socialist state securities and welfare, the extreme corruption in most governmental hierarchies, and the fracture of family units meant that women and children became especially exposed and vulnerable in times of trauma - they readily became targets for human traffickers. Natural disasters, epidemics, and armed violence also heightened the need for migration and alternative opportunities, many of which were actually disguised trafficking operations. As refugees seek out new homes in other nations and urban regions, they contribute to the migratory flow and 
supply of illegal smuggling operations and traffickers - subsequently, many stateless or homeless women and children became entrapped in the sex trafficking cartel, while young men were carted off into labour enslavement. The criminal market saw a whole world of opportunities open up in which they freely fed on and perpetuated the conditions of chaos. Their rise in pecuniary power and the immoral constitutes of governments led to a system of criminal control throughout many levels of government in destabilized regions and along borders, creating an evasive and aloof reality where human trade can be facilitated under the ignorant eye of the law. Globalization facilitated this process of growth, which has spanned over the course of the past 3 decades. Freer borders, trade, lax regulations, massively improved communications and technologies, and a globalized market demand for goods and services (including sexual services) under capitalist ideals rapidly grew larger, instigating a supply response from the international crime sector to broaden their methods and scope. Human trafficking, and specifically sex trafficking, is no longer confined by locality; it has bloomed into a melanoma of global proportions.

Overall the portrait of the human trafficking industry is one of enormous magnitude. Shelley $(2010,1-33)$ presents some statistics to demonstrate this, though data of this kind is inherently difficult to gather due to its nature of secrecy and the countless complications across international policies and politics of definitions. The human trafficking industry is observed to be pervasive in every single civilized continent, prevalent mostly in urbanizing areas and industrializing nations, though it by all means exists on a large scale in metropolises like Moscow and even in Portland, OR. The 
International Labour Organization reports in 2006 that there are 12.3 million people exploited through some kind of forced bondage. About 2.5 million are accounted victims of trafficking, two thirds of which are women and girls trafficked into sexual slavery, and about a third of mostly men and boys into labour slavery. The ILO also estimates that the annual revenue for the sex trafficking industry alone amounts to $\$ 33.9$ billion based on this record of 1.4 million sexually exploited people; the greatest profit margin of this trade came from the upper stratum of industrialized nations where wages are higher. I note that these figures are much higher in present times according to updated research, such as found in recent UN reports.

Shelley $(2010,113$ - 136) emphasizes that the international crime syndicates also operate with very diverse and multifaceted models, with some considering their human cargo like actual tradeable goods, as a depletable natural resource, even as pecuniary resources which are used to engage in immediate "conspicuous consumption". However, their similarities seem to lie in the low-risk factor of engaging in human trafficking and the promise of very high pecuniary profits, reinforcing the capitalist ideal of pecuniary predation. It is also analyzed throughout the book that the profits from this trade are often laundered and reinvested into businesses, financial securities, and even warfare, contributing to the global economy at large. Many countries, such as Thailand, are actually economically dependent on the sex tourism industry. Shelley $(2010,44-45)$ notes that the characteristic of the trafficking trade also tend to be characterized by economic conditioning, inequalities, and 
insufficiency in global development - many of which are correlated to the institutionalized status of women as a property or members of a lower class. Shelley $(2010,17)$ cites the 2008 economic crisis, which has had a disproportionately large effect on the growth in the sex trafficking of women and children, who are systematically the most vulnerable to the denial of entitlements and of impoverishment in times of economic turbulence. Even without going into economic theories of capitalism and its endemic financial crises, we may still conclude that human trafficking, especially sex trafficking of women and children, has many deeply rooted foundations in the heart of economic defects. Shelley $(2010,7)$ perfectly encapsulates this notion with a quote from Kevin Bale, a fellow antislavery advocate: "Indeed, the work of the modern slaveholder is best not seen as aberrant criminality but as a perfect example of disinterested capitalism.”

\section{Conclusion}

This inquiry has sought to expose the malignant foundation of women as a privatized property under patriarchal rule, and to demonstrate how this institution has evolved in tangent to become a naturalization of women and their children as sex slaves under the globalized and capitalist economy. With the current migrant crisis and numerous other conflicts, epidemics, and disasters going on in the world, we cannot ignore the implications of their involvement and influence towards the human trafficking case. It remains a fact that human trafficking has roots in economic disequilibrium, manifesting in the core of the family unit with the advent of ownership-marriage and the oppression of women in order to uphold the institutions of 
private property and male proprietorship. The disproportionate number of females, especially within ethnic minority groups, who suffer from trafficking is in direct correlation to their economic conditions prior to being trafficked. Women and girls, institutionally the dethroned mother and disowned daughter in the patriarchal household, are denied the proprietary status which could give them the power to escape economic stratifications and reduce their own vulnerability in troubled times. Human trafficking is a cancer of the deeply interwoven and dysfunctional institutions of the family unit, and of human society as a whole; it is bolstered by the age old genderclass bias in which men belong to the proprietary class and women to the subservient class, all the while copulating with the capitalist motives of privatization for profits and the sexual encumberment of the female sex. The upheaval of this industry, and the emancipation of women overall, requires a deep assessment of the evolutionary complexities and patterns of inequality which stem from ancient institutions; through this we may understand their trajectories and magnitudes. No single solution can be offered; however, it is clear that we must reassess our own agency, actions, and inactions. We as individuals have a duty to question the traditions and orientations we uphold as a society, which in tangible or intangible ways relate to and have consequences towards the human sex trafficking epidemic. Whether it be through better legislation, cooperative international policies, education, empowerment, equitable development, or etc., female emancipation is necessarily a prerequisite of the collective human vision and enactment towards a just and egalitarian world. 


\section{References}

Engels, Friedrich, and Eleanor Burke Leacock. The Origin of the Family, Private Property, and the State, in the Light of the Researches of Lewis H. Morgan. New York: International, 1972.Print.

Locke, John. "Second Treatise of Government." The Project Gutenberg. N.p., 28 July 2010. Web.

Shelley, Louise I. Human Trafficking: A Global Perspective. Cambridge: Cambridge UP, 2010. Print.

Veblen, Thorstein. "The Barbarian Status of Women." American Journal of Sociology 4.4 (1899): 503-14.Web.

Veblen, Thorstein. "The Beginnings of Ownership." American Journal of Sociology 4.3 (1898): 352-65. Web. 